\title{
Zespół Goodpasture’a wyzwaniem diagnostycznym i terapeutycznym dla lekarza kardiologa
}

\author{
Goodpasture's syndrome as a diagnostic \\ and therapeutic challenge for cardiologist
}

Anna Chuda, Małgorzata Lelonek

Klinika Kardiologii Katedry Kardiologii i Kardiochirurgii Uniwersytetu Medycznego w Łodzi

\section{Streszczenie}

W pracy przedstawiono przypadek kliniczny 67-letniego mężczyzny z gwałtownie postępującym kłębuszkowym zapaleniem nerek w przebiegu zespołu Goodpasteure'a, u którego wystąpił ostry zespół wieńcowy (ACS). Początkowe objawy pod postacią białkomoczu, krwinkomoczu i krwioplucia nasuwały rozpoznanie, które ostatecznie zostało potwierdzone w powtarzanych badaniach przeciwciał anty-GBM oraz w biopsji nerki, gdzie uwidoczniono obraz pozawłośniczkowego kłębuszkowego zapalenia nerek (postać z przeciwciałami IgG przeciw błonie podstawnej). W momencie rozpoznania chory prezentował także objawy niewydolności nerek, z oligurią, wymagał hemodializoterapii. Mężczyznę skutecznie leczono zabiegami wymiany osocza, steroidami i pulsami cyklofosfamidu. Niespodziewanie u pacjenta wystąpiły powikłania kardiologiczne pod postacią ostrego incydentu wieńcowego i epizodów migotania przedsionków. Ze względu na ryzyko zatorowe chory wymagał leczenia przeciwkrzepliwego, jednak przy tak wysokim ryzyku krwawienia, jakie występuje w zespole Goodpasteure’a, nie włączono tej terapii. Przedstawiony przypadek kliniczny pokazuje, że u każdego pacjenta z migotaniem przedsionków należy brać pod uwagę indywidualizację postępowania i szacowanie stosunku ryzyko-korzyści z rozważeniem nowych metod leczenia zmniejszających ryzyko zatorowe i minimalizujących powikłania krwotoczne. Słowa kluczowe: zespół płucno-nerkowy, gwałtownie postępujące kłębuszkowe zapalenie nerek, zespół Goodpasture'a, migotanie przedsionków, incydenty wieńcowe

Folia Cardiologica 2016; 11, 5: 433-439

\section{Wstęp}

Zespół Goodpasture'a to stosunkowo rzadko rozpoznawana, ale dobrze opisana jednostka chorobowa. Zespół ten najczęściej obejmuje płuca oraz nerki („klasyczny” zespół Goodpasture'a występuje w 60\% przypadków), ale może zajmować tylko jeden narząd: nerki (ok. 40\%) lub płuca (1-2\%). Zespół Goodpasture’a stanowi około 20\% przypadków zespołu płucno-nerkowego [1]. W klasycznej postaci jest to choroba wieloukładowa o podłożu autoimmunologicznym [2], należąca do układowych zapaleń naczyń. Za kliniczne objawy choroby odpowiada reakcja nadwrażliwości typu II prowadząca do wytworzenia przeciwciał przeciwko błonie podstawnej kłębuszków nerkowych, a dokładnie przeciwko kolagenowi typu IV. Proces ten niekiedy nasilają przeciwciała przeciw cytoplazmie neutrofilów (ANCA, anti-neutrophil cytoplasmic antibodies), występujące w różnym mianie u 10-38\% chorych [3]. W przebiegu zespołu Goodpasture'a dochodzi do gwałtownie postępującego kłębuszkowego zapalenia nerek i rozlanego krwawienia pęcherzykowego w płucach. Do zajęcia nerek dochodzi prawie zawsze. Objawy płucne u osób młodych występują w 70-80\%, natomiast u pacjentów powyżej 60 . roku życia znacznie rzadziej $(20 \%)[4,5]$. Choroba prawie 3-krotnie częściej występuje u mężczyzn ( $\mathrm{M:K}=2,6: 1$ ) [5]. Objawy mogą mieć zmienny charakter, z okresami poprawy, bądź od początku gwałtowny z bezpośrednim zagrożeniem życia. 


\section{Opis przypadku}

Pacjent w wieku 67 lat hospitalizowany w klinice reumatologii (21-24 kwietnia 2015 r.) z powodu podejrzenia zapalenia naczyń, zgłaszał dolegliwości bólowe stawów, blednięcie i ziębnięcie palców rąk i stóp z towarzyszącymi wybroczynami na podudziach oraz z krwawieniami z nosa, krwiopluciem, krwiomoczem i gorączką. Na podstawie obrazu klinicznego i przeprowadzonych badań dodatkowych ustalono rozpoznanie zespołu Churga-Straussa. Parametry nerkowe były prawidłowe. Włączono wówczas leczenie objawowe oraz rozpoczęto terapię immunosupresyjną. Podawano pulsy z metylprednizolonu, następnie prednizon doustnie oraz cyklofosfamid. W wyniku zastosowanego leczenia uzyskano istotne zmniejszenie dolegliwości. Po przejściowej poprawie stanu ogólnego po 4 dniach od wypisu z kliniki reumatologii chory został przyjęty do kliniki pulmonologii (28 kwietnia 2015 r.) z powodu utrzymującego się krwioplucia, z towarzyszącą gorączką do $39^{\circ} \mathrm{C}$. W badaniach laboratoryjnych wykonanych $w$ dniu przyjęcia parametry nerkowe były podwyższone: stężenie kreatyniny 525,0 $\mathrm{\mu mol} / \mathrm{l}$, mocznika $25,4 \mathrm{mmol} / \mathrm{l}$. Chorego przekazano do kliniki nefrologii (29 kwietnia - 20 maja 2015 r.). Objawy pod postacią: krwiomoczu, białkomoczu, obecności wałeczków czerwonokrwinkowych w moczu oraz niewydolności nerek nasuwały rozpoznanie postępującego kłębuszkowego zapalenia nerek. Ze względu na wysokie parametry stanu zapalnego (białko C-reaktywne [CRP, C-reactive protein] $246 \mathrm{mg} / \mathrm{l}$, prokalcytonina $6,38 \mu \mathrm{g} / \mathrm{l})$ u chorego włączono antybiotykoterapię szerokowidmową oraz odroczono wykonanie biopsji nerki do momentu ustabilizowania i zmniejszenia stanu zapalnego. Krwioplucie o coraz mniejszym nasileniu utrzymywało się jeszcze przez kilka dni. W badaniu RTG klatki piersiowej wykazano obecność masywnych zagęszczeń miąższowych w dolnym polu płucnym prawym i mniej nasilonych smużastych zagęszczeń zapalnych odwnękowo w środkowym i dolnym polu płucnym lewym.

U chorego 29/30 kwietnia 2015 roku pojawił się napad częstoskurczu przedsionkowego z częstością pracy komór 190/min, z hipotensją i towarzyszącym bólem stenokardialnym oraz rozległym niedokrwieniem w EKG pod postacią obniżeń odcinka ST o 2,5 mm z ujemnymi załamkami T w odprowadzeniach I, II, aVF oraz w odprowadzeniach przedsercowych V4-V6 z towarzyszącym uniesieniem odcinka ST w odprowadzeniu aVR (ryc. 1). Chorego zakwalifikowano do pilnej kardiowersji elektrycznej i przy użyciu energii $150 \mathrm{~J}$ uzyskano miarowy rytm zatokowy częstości 84/min oraz ustąpienie dolegliwości bólowych w klatce piersiowej. Podczas dalszej hospitalizacji nie obserwowano nawrotu zaburzeń rytmu serca.

Mimo zastosowanej intensywnej immunosupresji obserwowano pogarszanie parametrów nerkowych wymagające rozpoczęcia u chorego leczenia nerkozastępczego. Pierwszy
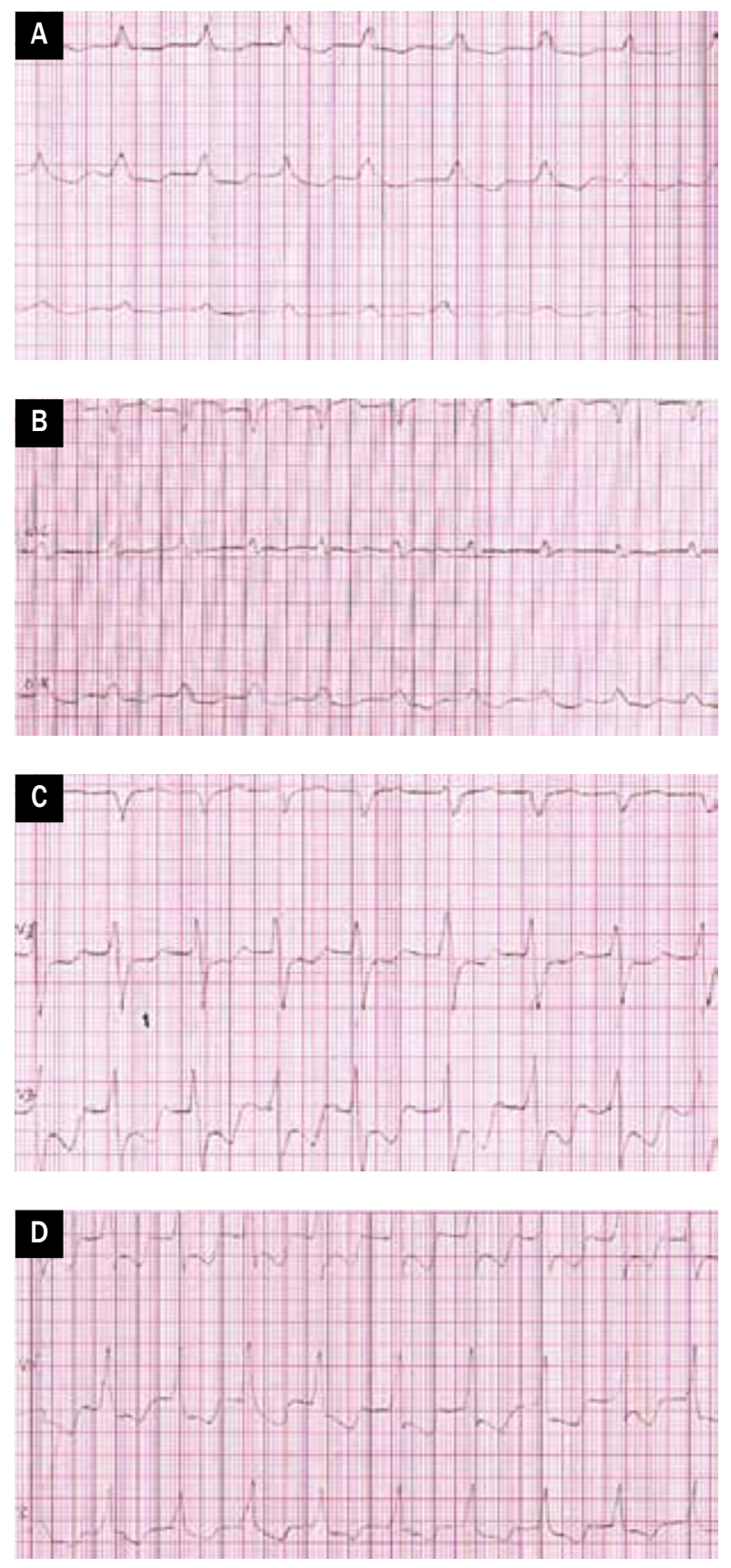

Rycina 1A-D. Zapis EKG z 29/30 kwietnia 2015 roku (przesunięcie papieru $50 \mathrm{~mm} / \mathrm{s}$; cecha $10 \mathrm{~mm} / 1 \mathrm{mV}$ )

zabieg hemodializy przeprowadzono 6 maja, odbył się bez powikłań. Następnego dnia wykonano biopsję nerki, której obraz odpowiadał pozawłośniczkowemu kłębuszkowemu zapaleniu nerek w postaci z przeciwciałami przeciw błonie podstawnej. Jednocześnie pobrano również krew na oznaczenie przeciwciał przeciw błonie podstawnej, przeciwjądrowych i przeciw cytoplazmie neutrofilów. Potwierdzono obecność anty-GBM w surowicy w mianie 320 w ocenie przeprowadzonej metodą immunofluorescencji pośredniej (IFF, indirect immunofluorescence method). Nie stwier- 
dzono przeciwciał przeciwko cytoplazmie neutrofili (ANCA, antineutrophil cytoplasmic antibodies) ani przeciwciał przeciwjądrowych (ANA, antinuclear antibodies). Rozpoznano zespół Goodpasture'a. Wykonano kolejne zabiegi hemodializy. Po otrzymaniu wyniku z biopsji nerki zdecydowano również o wykonaniu serii plazmaferez.

Obserwowano stopniową stabilizację obrazu klinicznego oraz parametrów nerkowych. Ze względu na dodatkowy incydent krwawienia podczas ostatniego zabiegu hemodializy (podkrwawianie z rany wargi górnej) 20 maja 2015 roku odstąpiono od kontynuacji zabiegów hemodializ. Biorąc pod uwagę wysokie ryzyko krwawienia, zaprzestano także kontynuacji plazmaferez. Ostatecznie w wyniku zastosowanego leczenia farmakologicznego uzyskano ustąpienie objawów klinicznych, normalizację CRP i zmniejszenie miana anty-GBM do 80. W nieznacznym stopniu poprawiła się funkcja nerek (wskaźnik filtracji kłębuszkowej [GFR, glomerular filtration rate] $16,0 \mathrm{ml} / \mathrm{min} / 1,73 \mathrm{~m}^{2}$ ).

$\mathrm{U}$ chorego po nieznacznym wysiłku $18 / 19$ maja 2015 roku wystąpił kolejny epizod silnego bólu w klatce piersiowej o charakterze typowego bólu wieńcowego z towarzyszącymi rozległymi zmianami niedokrwiennymi w zapisie EKG: obniżenia odcinka ST w odprowadzeniach I, II, III, aVL, aVF, V2-V6 z ujemnym załamkiem T w migotaniu przedsionków (AF, atrial fibrillation). Włączono wlew dożylny nitrogliceryny, $75 \mathrm{mg}$ kwasu acetylosalicylowego (ASA, acetylsalicylic acid) oraz $100 \mathrm{mg}$ bursztynianu metoprololu. Po zastosowanym leczeniu po 30 min bóle ustąpiły oraz wycofały się zmiany niedokrwienne w EKG, z konwersją do rytmu zatokowego 75/min. Stężenia hsTnT i frakcji sercowej kinazy kreatynowej (CK-MB, creatine kinase myocardial bound) znajdowały się w granicach referencyjnych. W ocenie echokardiograficznej przezklatkowej uwidoczniono niewielkie odcinkowe zaburzenia kurczliwości ścian lewej komory z prawidłową funkcją skurczową lewej i prawej komory. Po konsultacji kardiologicznej rozpoznano ostry zespół wieńcowy (ACS, acute coronary syndrome) i chorego zakwalifikowano do diagnostyki inwazyjnej. Wynik w skali TIMI dla niestabilnej dławicy piersiowej (UA, unstable angina) i/lub zawału serca bez uniesienia odcinka ST (NSTEMI, non ST-segment elevation myocardial infarction) wynosił 4 punkty, co daje 19,9-procentowe ryzyko zgonu z powodu zawału serca lub nawrotu niedokrwienia wymagającego pilnej rewaskularyzacji w ciągu 14 dni. Wynik w skali GRACE przy przyjęciu do kliniki kardiologii był równy 137 punktów, co daje 2-procentowe ryzyko zgonu w szpitalu oraz 5-procentowe ryzyko zgonu w ciągu 6 miesięcy.

W wykonanej 20 maja 2015 roku koronarografii uwidoczniono wielonaczyniową chorobę wieńcową, w której stwierdzono brak pnia lewej tętnicy wieńcowej z niezależnym odejściem lewej gałęzi przedniej zstępującej (LAD, left anterior descending) i tętnicy okalającej (Cx, circumflex); w LAD wykazano zwężenie w ujściu, proksymalnie kompleksowe zwężenie o 95\% oraz nasilone zmiany przyścienne z dystalnym krótkim zwężeniem o 80\%, w Cx - w ujściu redukcja o około 40\%, tuż poniżej zwężenie o 60\%, w prawej tętnicy wieńcowej (RCA, right coronary artery) w części zstępującej zwężenie o 30\%, poniżej zwężenie o 75\% nad odejściem gałęzi do brzegu ostrego.

Po konsultacji zespołu Heart Team (grupa lekarzy specjalistów: kardiochirurg, kardiolog, echokardiografista, kardiolog inwazyjny) wykonano paliatywną przezskórną angioplastykę wieńcową ( $\mathrm{PCl}$, percutaneous coronary intervention) LAD w segmencie 6 z implantacją stentu uwalniającego sirolimus (DES, drug eluting stent) Avangarde $^{\mathrm{TM}} 4,0 / 25 \mathrm{~mm} z$ dobrym wynikiem angiograficznym, przepływ końcowy III w skali TIMI (naczynie o prawidłowym przepływie). Odstąpiono od rewaskularyzacji chirurgicznej ze względu na duże ryzyko krwawień oraz niski GFR równy $11,9 \mathrm{ml} / \mathrm{min} / 1,73 \mathrm{~m}^{2}$. Chorego zakwalifikowano do dalszego leczenia zachowawczego. Włączono podwójną terapię przeciwpłytkową (DAPT, dual antiplatelet therapy): ASA $75 \mathrm{mg}$ z klopidogrelem $75 \mathrm{mg}$. Wobec napadowego AF oceniono pacjenta w skali $\mathrm{CHA}_{2} \mathrm{DS}_{2}$ VASc, uzyskując punktacje 3, co odpowiada dość dużemu rocznemu ryzyku wystąpienia powikłań zakrzepowo-zatorowych (3,2\% rocznie). Wysoka punktacja w skali HAS-BLED (5 pkt.) przekłada się na bardzo wysokie roczne ryzyko krwawienia (9,1-12,50\%/rok), dlatego ostatecznie nie zdecydowano się na włączenie doustnych antykoagulantów (OAC, oral anticoagulants) u pacjenta z przebytymi krwawieniami w wywiadzie.

U chorego 23/24 maja 2015 roku wystąpiło ponowne podkrwawianie z wargi górnej, okresowe krwawienie z nosa, krwawienie z okolicy odbytu/żylaków odbytu (hemoglobina [Hb] 9 g/dl, płytki krwi [PLT, platelets] 90 tys.), które leczono zachowawczo i utrzymano dotychczasową terapię przeciwpłytkową ze względu na nieodległą interwencję wieńcową. Chorego w stanie ogólnym dobrym wypisano do domu z zaleceniami kontynuacji leczenia w warunkach ambulatoryjnych (poradnie nefrologiczna i kardiologiczna).

W kolejnych 2 miesiącach pacjent był hospitalizowany oraz obserwowany w izbie przyjęć z powodu dwóch napadów AF, które trwały maksymalnie do kilkunastu godzin z samoistną konwersją do rytmu zatokowego. Ze względu na wysokie ryzyko krwawien, liczne podbiegnięcia krwawe oraz niski GFR 20-25 ml/min/1,73 $\mathrm{m}^{2}$ nie włączano leczenia przeciwzakrzepowego. Utrzymano stosowanie DAPT.

\section{Omówienie}

Pacjent z zespołem Goodpasteure'a stanowi wyzwanie dla lekarza kardiologa. Szczególnie gdy jest to pacjent obciążony dodatkowo wywiadem AF i wymaga leczenia przeciwkrzepliwego. W leczeniu AF obowiązują standardy postępowania Europejskiego Towarzystwa Kardiologicznego (ESC, European Society of Cardiology) [6]. Z amerykańskiej bazy danych Renal Data System wiadomo, że przewlekła choroba nerek (CKD, chronic kidney disease) i jej końcowe 
Tabela 1. Powikłania krwotoczne u pacjentów z migotaniem przedsionków i niewydolnością nerek (wg [10], zmodyfikowano)

\begin{tabular}{lcccc} 
Krwawienia & $\begin{array}{c}\text { Ogółem } \\
\mathrm{n}(\%)\end{array}$ & $\begin{array}{c}\text { Pacjenci bez } \\
\text { choroby nerek } \\
\mathrm{n}(\%)\end{array}$ & $\begin{array}{c}\text { Choroba nerek } \\
\text { w wyższym stadium } \\
\mathrm{n}(\%)\end{array}$ & $\begin{array}{c}\text { Chorzy dializowani } \\
n(\%)\end{array}$ \\
\hline Krwawienia ogółem & $17535(100)$ & $16195(100)$ & $1097(100)$ & $243(100)$ \\
Krwawienia niezakończone zgonem & $15003(85,6)$ & $13872(85,7)$ & $923(84,1)$ & $208(85,6)$ \\
Krwawienia z przewodu pokarmowego & $4995(28,5)$ & $4555(28,1)$ & $353(32,2)$ & $87(35,8)$ \\
Krwawienie śródczaszkowe & $1648(9,4)$ & $1574(9,7)$ & $57(5,2)$ & $17(7,0)$ \\
Krwawienie z układu moczowego & $4123(23,5)$ & $3768(23,3)$ & $301(27,4)$ & $54(22,2)$ \\
Krwawienia do płuc & $4237(24,2)$ & $3975(24,5)$ & $212(19,3)$ & $50(20,6)$ \\
Krwawienie zakończone zgonem & $2532(14,4)$ & $2323(14,3)$ & $174(15,9)$ & $35(14,4)$ \\
Krwawienie z przewodu pokarmowego & $967(5,5)$ & $863(5,3)$ & $89(8,1)$ & $15(6,2)$ \\
Krwawienie śródczaszkowe & $1495(8,5)$ & $1401(8,7)$ & $76(6,9)$ & $18(7,4)$ \\
Krwawienie z układu moczowego & $29(0,2)$ & $22(0,1)$ & $6(0,5)$ & $1(0,4)$
\end{tabular}

stadium wymagające terapii zastępczej zwiększają ryzyko udaru mózgu odpowiednio 3,7- i 5,8-krotnie [7]. Z kolei w badaniu Wiesholzera i wsp. [8] terapia antagonistami witaminy $\mathrm{K}$ (VKA, vitamin $\mathrm{K}$ antagonists) lub ASA w grupie 430 przewlekle dializowanych pacjentów wiązała się z 8,3-krotnym wzrostem ryzyka wystąpienia udaru mózgu, niezależnie od towarzyszącego AF. Dodatkowo Vázquez i wsp. [9] zaobserwowali u chorych wymagających terapii nerkozastępczej częstsze występowanie powikłań krwotocznych, które wynosiło $26 \%$ rocznie u osób przyjmujących VKA, 16\% u pacjentów stosujących terapię przeciwpłytkową i 11\% u chorych niestosujących leczenia przeciwzakrzepowego i przeciwpłytkowego. Zatem w takim przypadku klinicznym należy starannie ocenić ryzyko powikłań krwotocznych, biorąc jednocześnie pod uwagę narażenie na incydenty zatorowe przy zaniechaniu terapii przeciwzakrzepowej.

Długotrwała terapia przeciwkrzepliwa w CKD może potęgować poważne powikłania krwotoczne wymienione w tabeli 1 [10]. Z kolei grupą szczególnie narażoną na występowanie powikłań zatorowych w obserwacji odległej są pacjenci z CKD, u których stwierdza się występowanie przynajmniej jednego z dodatkowych czynników (tab. 2) [10]. Natomiast wystąpienie ciężkich powikłań krwotocznych $w$ trakcie stosowania VKA może nasilać wiele niezależnych czynników (tab. 3) [10]. Według literatury krwawienia będą najrzadziej występować, jeśli podczas stosowania VKA wartość współczynnika znormalizowanego (INR, international normalized ratio) mieści się w przedziale 2,0-2,9. Ryzyko poważnych krwawień istotnie wzrasta, gdy wartość INR przekracza 4,5 i zwiększa się wykładniczo powyżej 6,0. W celu obliczenia ryzyka powikłań krwotocznych należy stosować skalę HAS-BLED, w której punktacja co najmniej 3 oznacza „wysokie ryzyko" wymagające częstej systematycznej kontroli INR po rozpoczęciu leczenia przeciwzakrzepowego OAC lub terapii przeciwpłytkowej (poziom wiarygodności danych A) [6].
Alternatywą dla VKA są nowsze doustne leki przeciwzakrzepowe: bezpośredni inhibitor trombiny (dabigatran) lub doustny inhibitor czynnika Xa (np. riwaroksaban, apiksaban). W grupie chorych z CKD stosowanie tych leków ogranicza jednak czynność nerek. Nie zaleca się bowiem stosowania dabigatranu u chorych z ciężką niewydolnością nerek (klirens kreatyniny $<30 \mathrm{ml} / \mathrm{min}$ ). Już umiarkowane upośledzenie czynności nerek (klirens kreatyniny 30-49 ml/min) nakazuje zmniejszenie dawki dabigatranu do $110 \mathrm{mg} 2$ razy dziennie, a rywaroksabanu do $15 \mathrm{mg}$ raz dziennie przy klirensie kreatyniny 15-49 ml/min, apiksabanu zaś do 2,5 mg 2 razy dziennie przy klirensie kreatyniny $15-29 \mathrm{ml} / \mathrm{min}$. Nie są to więc leki dla pacjentów obarczonych chorobą nerek z niskim GFR [6].

Alternatywą dla farmakoterapii takich pacjentów może być procedura polegająca na zamknięciu uszka lewego przedsionka (LAA, left atrial appendage), która powinna być przede wszystkim rozważana u chorych, którzy doświadczyli już poważnego krwawienia w trakcie leczenia VKA lub ryzyko krwawienia jest u nich wysokie (np. są dializowani lub z marskością wątroby).W badaniu PROTECT AF [11] wykazano, że skuteczność zamknięcia LAA jest co najmniej równoważna do terapii warfaryną pod względem zapobiegania udarom, zatorom obwodowym oraz zgonom sercowo-naczyniowym. Zabieg zamknięcia LAA jednak jest obarczony występowaniem powikłań okołointerwencyjnych, głównie dużego krwawienia, tamponady serca oraz niecałkowitego zamknięcia LAA [6]. Na podstawie tych danych ESC w wytycznych dotyczących postępowania u pacjentów z AF przyznało zabiegowi zamknięcia LAA klasę rekomendacji Ilb/B[6] dla chorych wysokiego ryzyka udaru mózgu i z przeciwwskazaniami do długotrwałej antykoagulacji doustnej (klasa rekomendacji IIb/B).

Dla pacjentów obarczonych wysokim ryzykiem krwawień i wymagających PCl rozwiązaniem mogą być nowe stenty 
Tabela 2. Czynniki ryzyka zdarzeń zakrzepowo-zatorowych w odniesieniu do niewydolności nerek $w$ trakcie terapii antagonistami witaminy $\mathrm{K}$ i/lub kwasu acetylosalicylowego (ASA, acetylsalicylic acid) (wg [10], zmodyfikowano)

\begin{tabular}{|c|c|c|c|c|c|c|c|c|}
\hline \multirow[t]{2}{*}{ Charakterystyka } & \multicolumn{2}{|c|}{ Ogółem } & \multicolumn{2}{|c|}{ Bez choroby nerek } & \multicolumn{2}{|c|}{ Niewydolność nerek } & \multicolumn{2}{|c|}{ Hemodializoterapia } \\
\hline & $\begin{array}{c}n=132372 \\
\text { HR } \\
(95 \% \mathrm{Cl})\end{array}$ & $\mathbf{p}$ & $\begin{array}{c}n=127884 \\
H R \\
(95 \% \mathrm{Cl})\end{array}$ & p & $\begin{array}{c}n=3587 \\
H R \\
(95 \% \mathrm{Cl})\end{array}$ & p & $\begin{array}{c}n=901 \\
H R \\
(95 \% \mathrm{Cl})\end{array}$ & p \\
\hline Wszyscy pacjenci & & & 1,00 & & $\begin{array}{c}1,49 \\
(1,38-1,59)\end{array}$ & $<0,001$ & $\begin{array}{c}1,83 \\
(1,57-2,14)\end{array}$ & $<0,001$ \\
\hline \multicolumn{9}{|l|}{ Terapia przeciwkrzepliwa } \\
\hline $\begin{array}{l}\text { Bez terapii przeciw- } \\
\text { krzepliwej }\end{array}$ & 1,00 & & 1,00 & & 1,00 & & 1,00 & \\
\hline Warfaryna & $\begin{array}{c}0,59 \\
(0,57-0,62)\end{array}$ & $<0,001$ & $\begin{array}{c}0,59 \\
(0,56-0,61)\end{array}$ & $<0,001$ & $\begin{array}{c}0,84 \\
(0,69-1,01)\end{array}$ & 0,07 & $\begin{array}{c}0,44 \\
(0,26-0,74)\end{array}$ & 0,002 \\
\hline ASA & $\begin{array}{c}1,11 \\
(1,07-1,15)\end{array}$ & $<0,001$ & $\begin{array}{c}1,10 \\
(1,06-1,14)\end{array}$ & $<0,001$ & $\begin{array}{c}1,25 \\
(1,07-1,47)\end{array}$ & 0,01 & $\begin{array}{c}0,88 \\
(0,59-1,32)\end{array}$ & 0,54 \\
\hline Warfaryna i ASA & $\begin{array}{c}0,70 \\
(0,65-0,75)\end{array}$ & $<0,001$ & $\begin{array}{c}0,69 \\
(0,64-0,74)\end{array}$ & $<0,001$ & $\begin{array}{c}0,76 \\
(0,56-1,03)\end{array}$ & 0,08 & $\begin{array}{c}0,82 \\
(0,37-1,80)\end{array}$ & 0,62 \\
\hline \multicolumn{9}{|c|}{ Czynniki ryzyka zakrzepowego } \\
\hline \multicolumn{9}{|c|}{ Zastoinowa niewydolność serca } \\
\hline Dysfunkcja lewej komory & $\begin{array}{c}1,03 \\
(0,99-1,07)\end{array}$ & 0,18 & $\begin{array}{c}1,03 \\
(0,99-1,08)\end{array}$ & 0,11 & $\begin{array}{c}0,98 \\
(0,84-1,14)\end{array}$ & 0,78 & $\begin{array}{c}0,96 \\
(0,64-1,43)\end{array}$ & 0,84 \\
\hline Nadciśnienie tętnicze & $\begin{array}{c}1,06 \\
(1,03-1,09)\end{array}$ & $<0,001$ & $\begin{array}{c}1,05 \\
(1,02-1,09)\end{array}$ & 0,002 & $\begin{array}{c}1,13 \\
(0,98-1,30)\end{array}$ & 0,10 & $\begin{array}{c}1,05 \\
(0,76-1,45)\end{array}$ & 0,78 \\
\hline \multicolumn{9}{|l|}{ Wiek } \\
\hline$\geq 75$ lat & $\begin{array}{c}3,48 \\
(3,31-3,66)\end{array}$ & $<0,001$ & $\begin{array}{c}3,56 \\
(3,38-3,76)\end{array}$ & $<0,001$ & $\begin{array}{c}1,87 \\
(1,48-2,36)\end{array}$ & $<0,001$ & $\begin{array}{c}2,46 \\
(1,60-3,79)\end{array}$ & $<0,001$ \\
\hline $65-74$ lat & $\begin{array}{c}2,02 \\
(1,91-2,14)\end{array}$ & $<0,001$ & $\begin{array}{c}2,03 \\
(1,92-2,16)\end{array}$ & $<0,001$ & $\begin{array}{c}1,52 \\
(1,18-1,94)\end{array}$ & 0,001 & $\begin{array}{c}2,18 \\
(1,46-3,24)\end{array}$ & $<0,001$ \\
\hline Cukrzyca & $\begin{array}{c}1,32 \\
(1,26-1,38)\end{array}$ & $<0,001$ & $\begin{array}{c}1,32 \\
(1,25-1,39)\end{array}$ & $<0,001$ & $\begin{array}{c}1,16 \\
(0,99-1,36)\end{array}$ & 0,07 & $\begin{array}{c}1,41 \\
(0,95-2,10)\end{array}$ & 0,09 \\
\hline \multicolumn{9}{|c|}{ Przebyty udar mózgu/przemijający atak niedokrwienny } \\
\hline $\begin{array}{l}\text { Incydent zakrzepowo- } \\
\text {-zatorowy }\end{array}$ & $\begin{array}{c}3,20 \\
(3,10-3,31)\end{array}$ & $<0,001$ & $\begin{array}{c}3,24 \\
(3,14-3,35)\end{array}$ & $<0,001$ & $\begin{array}{c}2,71 \\
(2,34-3,15)\end{array}$ & $<0,001$ & $\begin{array}{c}1,99 \\
(1,36-2,91)\end{array}$ & $<0,001$ \\
\hline Choroba naczyniowa & $\begin{array}{c}1,10 \\
(1,06-1,15)\end{array}$ & $<0,001$ & $\begin{array}{c}1,12 \\
(1,07-1,16)\end{array}$ & $<0,001$ & $\begin{array}{c}0,89 \\
(0,76-1,05)\end{array}$ & 0,17 & $\begin{array}{c}1,11 \\
(0,78-1,58)\end{array}$ & 0,57 \\
\hline Płeć żeńska & $\begin{array}{c}1,1 \\
(1,08-1,15)\end{array}$ & $<0,001$ & $\begin{array}{c}1,12 \\
(1,08-1,15)\end{array}$ & $<0,001$ & $\begin{array}{c}1,06 \\
(0,92-1,22)\end{array}$ & 0,44 & $\begin{array}{c}1,34 \\
(0,97-1,85)\end{array}$ & 0,08 \\
\hline
\end{tabular}

HR (hazard ratio) - hazard względny; Cl (confidence interval) - przedział ufności

BioFreedom ${ }^{\mathrm{TM}}$. BioFreedom ${ }^{\mathrm{TM}}$ łączy w sobie zalety stentu uwalniającego lek z nagim stentem metalowym (BMS, bare-metal stent). Połączenie selektywnej mikrostruktury powierzchni pokrywającej stent i szybkiego transferu leku BA9 ${ }^{\text {TM }}$ bez udziału polimerów lub przekaźników sprawia, że po wszczepieniu stentu BioFreedom ${ }^{\mathrm{TM}}$ można skrócić stosowanie DAPT do 28 dni [12]. Wydaje się, że stent BioFreedom ${ }^{\mathrm{TM}}$ byłby najbardziej odpowiednim wyborem dla pacjentów wysokiego ryzyka krwawienia, tak jak w opisanym przypadku.

\section{Podsumowanie}

W niniejszej pracy przedstawiono przypadek kliniczny mężczyzny z zespołem Goodpasteure'a, leczonego efektywnie zabiegami wymiany osocza, steroidami i pulsami cyklofosfamidu, u którego wystąpiły powikłania kardiologiczne pod postacią ACS i szybkiego AF. Chory wymagał leczenia przeciwkrzepliwego, jednak z powodu wysokiego ryzyka krwawienia nie włączono tej terapii. Warto podkreślić, że w każdym przypadku klinicznym obowiązują indywidualizacja postępowania i szacowanie stosunku ryzyko-korzyści z rozważeniem nowych metod leczenia zmniejszających ryzyko zatorowe i jednocześnie minimalizujących powikłania krwotoczne.

\section{Konflikt interesów}

Autorki deklarują brak konfliktu interesów 
Tabela 3. Czynniki ryzyka dla krwawienia w odniesieniu do niewydolności nerek w trakcie terapii antagonistami witaminy $\mathrm{K}$ i/lub kwasu acetylosalicylowego (ASA, acetylsalicylic acid) (wg [10], zmodyfikowano)

\begin{tabular}{|c|c|c|c|c|c|c|c|c|}
\hline \multirow[t]{2}{*}{ Charakterystyka } & \multicolumn{2}{|c|}{ Ogółem } & \multicolumn{2}{|c|}{ Bez choroby nerek } & \multicolumn{2}{|c|}{ Niewydolność nerek } & \multicolumn{2}{|c|}{ Hemodializoterapia } \\
\hline & $\begin{array}{c}\mathrm{n}=132372 \\
\mathrm{HR} \\
(95 \% \mathrm{Cl})\end{array}$ & $\mathbf{p}$ & $\begin{array}{c}n=127884 \\
\text { HR } \\
(95 \% \mathrm{Cl})\end{array}$ & p & $\begin{array}{c}n=3587 \\
\text { HR } \\
(95 \% \mathrm{Cl})\end{array}$ & $\mathbf{p}$ & $\begin{array}{c}n=901 \\
\text { HR } \\
(95 \% \mathrm{Cl})\end{array}$ & p \\
\hline Wszyscy pacjenci & & & 1,00 & & $\begin{array}{c}2,24 \\
(2,10-2,38)\end{array}$ & $<0,001$ & $\begin{array}{c}2,70 \\
(2,38-3,07)\end{array}$ & $<0,001$ \\
\hline \multicolumn{9}{|l|}{ Terapia przeciwkrzepliwa } \\
\hline $\begin{array}{l}\text { Bez terapii przeciw- } \\
\text { krzepliwej }\end{array}$ & 1,00 & & 1,00 & & 1,00 & & 1,00 & \\
\hline Warfaryna & $\begin{array}{c}1,28 \\
(1,23-1,33)\end{array}$ & $<0,001$ & $\begin{array}{c}1,28 \\
(1,23-1,33)\end{array}$ & $<0,001$ & $(1,23-1,33)$ & $<0,001$ & $\begin{array}{c}1,27 \\
(0,91-1,77)\end{array}$ & 0,15 \\
\hline ASA & $\begin{array}{c}1,21 \\
(1,16-1,26)\end{array}$ & $<0,001$ & $\begin{array}{c}1,21 \\
(1,16-1,26)\end{array}$ & $<0,001$ & $(1,16-1,26)$ & 0,14 & $\begin{array}{c}1,63 \\
(1,18-2,26)\end{array}$ & 0,003 \\
\hline Warfaryna i ASA & $\begin{array}{c}2,15 \\
(2,04-2,26)\end{array}$ & $<0,001$ & $\begin{array}{c}2,18 \\
(2,07-2,30)\end{array}$ & $<0,001$ & $\begin{array}{c}1,63 \\
(1,32-2,02)\end{array}$ & $<0,001$ & $\begin{array}{c}1,71 \\
(0,98-2,99)\end{array}$ & 0,06 \\
\hline \multicolumn{9}{|l|}{ Czynniki ryzyka krwawienia } \\
\hline Nadciśnienie tętnicze & $\begin{array}{c}1,01 \\
(0,98-1,04)\end{array}$ & 0,52 & $\begin{array}{c}1,01 \\
(0,98-1,04)\end{array}$ & 0,58 & $\begin{array}{c}0,99 \\
(0,87-1,11)\end{array}$ & 0,81 & $\begin{array}{c}0,92 \\
(0,71-1,20)\end{array}$ & 0,55 \\
\hline $\begin{array}{l}\text { Nieprawidłowa czynność } \\
\text { nerek lub wątroby }\end{array}$ & $\begin{array}{c}1,37 \\
(1,23-1,52)\end{array}$ & $<0,001$ & $\begin{array}{c}1,40 \\
(1,25-1,57)\end{array}$ & $<0,001$ & $\begin{array}{c}1,31 \\
(0,90-1,91)\end{array}$ & 0,16 & $\begin{array}{c}0,74 \\
(0,34-1,64)\end{array}$ & 0,46 \\
\hline Udar mózgu & $\begin{array}{c}1,23 \\
(1,18-1,28)\end{array}$ & $<0,001$ & $\begin{array}{c}1,24 \\
(1,19-1,30)\end{array}$ & $<0,001$ & $\begin{array}{c}1,04 \\
(0,89-1,22)\end{array}$ & 0,62 & $\begin{array}{c}0,93 \\
(0,63-1,36)\end{array}$ & 0,70 \\
\hline Krwawienie & $\begin{array}{c}2,44 \\
(2,33-2,55)\end{array}$ & $<0,001$ & $\begin{array}{c}2,54 \\
(2,42-2,67)\end{array}$ & $<0,001$ & $\begin{array}{c}1,70 \\
(1,45-1,99)\end{array}$ & $<0,001$ & $\begin{array}{c}2,09 \\
(1,50-2,91)\end{array}$ & $<0,001$ \\
\hline Wiek $\geq 65$ lat & $\begin{array}{c}2,09 \\
(2,00-2,17)\end{array}$ & $<0,001$ & $\begin{array}{c}2,12 \\
(2,03-2,20)\end{array}$ & $<0,001$ & $\begin{array}{c}1,61 \\
(1,35-1,92)\end{array}$ & $<0,001$ & $\begin{array}{c}1,36 \\
(1,03-1,80)\end{array}$ & 0,03 \\
\hline $\begin{array}{l}\text { Przyjmowanie leków } \\
\text { przeciwpłytkowych lub NLPZ }\end{array}$ & $\begin{array}{c}1,12 \\
(1,08-1,16)\end{array}$ & $<0,001$ & $\begin{array}{c}1,12 \\
(1,08-1,17)\end{array}$ & $<0,001$ & $\begin{array}{c}1,10 \\
(0,96-1,26)\end{array}$ & 0,19 & $\begin{array}{c}0,91 \\
(0,62-1,33)\end{array}$ & 0,63 \\
\hline Alkohol & $\begin{array}{c}1,40 \\
(1,30-1,52)\end{array}$ & $<0,001$ & $\begin{array}{c}1,43 \\
(1,32-1,56)\end{array}$ & $<0,001$ & $\begin{array}{c}1,01 \\
(0,73-1,39)\end{array}$ & 0,97 & $\begin{array}{c}1,33 \\
(0,70-2,54)\end{array}$ & 0,39 \\
\hline
\end{tabular}

HR (hazard ratio) - hazard względny; Cl (confidence interval) - 95-procentowy przedział ufności; NLPZ - niesteroidowe leki przeciwzapalne

\section{Abstract}

We describe a case of 67-year-old man, with rapidly progressive crescentic glomerulonephritis in the course of Goodpasture's syndrome and acute coronary syndrome (ACS). The disease was initially presented with proteinuria and hematuria on urinalysis and hemoptysis. Immunologic tests for anti-GBM Ab were positive. At the time of diagnosis the patient presented with renal insufficiency with oliguria requiring hemodialysis but without pulmonary hemorrhage. Renal biopsy showed cellular crescents in all glomeruli with linear deposition of IgG along the GBM. Repeated testing showed anti-GBM Ab. The patient received pulse cyclophosphamide, and pulse methylprednisolone continued by oral prednisone, and consecutive plasma exchange treatment. The patient had cardiac complications in the form of coronary events and tachyarrhythmias (atrial fibrillation). Because of the risk of thromboembolism he required anticoagulation, but with such a high risk of bleeding the therapy has not been started. The case confirms that for each patient with atrial fibrillation we need to individually assess the risks and benefits of our treatment and consider new treatments that reduce the embolic risk and minimize bleeding complications.

Key words: pulmonary-renal syndrome, rapidly progressive glomerulonephritis, Goodpasture's syndrome, atrial fibrillation, coronary events

Folia Cardiologica 2016; 11, 5: 433-439 


\section{Piśmiennictwo}

1. Pusey C.D. Anti-glomerular basement membrane disease. Kidney Int. 2003; 64: 15-35.

2. Ho J., Gibson I.W., Zacharias J. i wsp. Antigenic heterogeneity of IgA anti-GBM disease: new renal targets of IgA autoantibodies. Am. J. Kidney Dis. 2008; 4: 761-765.

3. Rutkowski P., Rutkowski B., Książek A. i wsp. Nefrologia. Czelej, Lublin 2004: 423.

4. Phelps R.G., Rees A.J. The HLA complex in Goodpasture's disease: a model for analyzing susceptibility to autoimmunity. Kidney Int. 1999; 5: 1638-1553.

5. Herold G., Kokot F. Choroby nerek. Szybko postępujące kłębuszkowe zapalenie nerek. W: Herold G. (red.). Medycyna wewnętrzna. Wydawnictwo Lekarskie PZWL, Warszawa 2004: 725-726.

6. Wytyczne ESC dotyczące postępowania w migotaniu przedsionków na 2012 rok. Opracowane przy współpracy z European Heart Rhythm Association (EHRA). Kardiol. Pol. 2012; 70: 197-234.

7. Wizemann V., Tong L., Satayathum S. i wsp. Atrial fibrillation in hemodialysis patients: clinical features and associations with anticoagulant therapy. Kidney Int. 2010; 77: 1098-1106.
8. Wiesholzer M., Harm F., Tomasec G. i wsp. Incidence of stroke among chronic hemodialysis patients with nonrheumatic atrial fibrillation. Am. J. Nephrol. 2001; 21: 35-39.

9. Vázquez E., Sánchez-Perales C., García-Cortes M.J. i wsp. Ought dialysis patients with atrial fibrillation be treated with oral anticoagulants? Int. J. Cardiol. 2003; 87: 135-139.

10. Olesen J.B., Lip G.Y.H., Kamper A.L. i wsp. Stroke and bleeding in atrial fibrillation with chronic kidney disease. N. Engl. J. Med. 2012; 367: 625-635.

11. Holmes D.R., Reddy V.Y., Turi Z.G. i wsp.; PROTECT AF Investigators. Percutaneous closure of the left atrial appendage versus warfarin therapy for prevention of stroke in patients with atrial fibrillation: a randomized non-inferiority trial. Lancet 2009; 374: 534-542.

12. Dostępne na: http://www.biosensors.com/intl/sites/default/files/ /pdfs/products_technology/Biofreedom/11524-000-en_30640_freebro_main2015_210x297_r01d2a_Ir.pdf. Data dostępu:30.12.2015 r. 